\title{
Ribulose-1,5-bisphosphate Carboxylase/Oxygenase and Carbon Assimilation in Methylococcus capsulatus (Bath)
}

\author{
By STEPHEN C. TAYLOR, $\dagger$ HOWARD DALTON AND \\ CRAWFORD S. DOW* \\ Department of Biological Sciences, University of Warwick, Coventry CV4 7AL
}

(Received 28 July 1980)

\begin{abstract}
Intact cells of chemostat-grown Methylococcus capsulatus (Bath) assimilated $\mathrm{CO}_{2}$ such that approximately $2.5 \%(\mathrm{w} / \mathrm{w})$ of cell carbon arose from $\mathrm{CO}_{2}$ during growth with methane as carbon substrate. Radiolabelling studies suggested that $\mathrm{CO}_{2}$ was fixed by both ribulose1,5-bisphosphate (RuBP) carboxylase and known heterotrophic mechanisms. The pattern of $\mathrm{CO}_{2}$ fixation was similar to that in heterotrophically grown autotrophs. Enzyme analysis suggested the presence of a complete Calvin cycle but attempts to grow the organism autotrophically were unsuccessful. A specific phosphoglycollate phosphatase, required for the metabolism of phosphoglycollate arising as a result of RuBP oxygenase activity, was present. The product of this reaction, glycollate, was further metabolized by reactions of the serine cycle, used for $\mathrm{C}_{1}$ assimilation in type II methylotrophs. The possession of this pathway explains both the presence of hydroxypyruvate reductase and the results of $\left[{ }^{14} \mathrm{C}\right]$ formate uptake reported by other workers. The relationship between RuBP carboxylase/oxygenase and net carbon assimilation is discussed.
\end{abstract}

\section{INTRODUCTION}

Most methane-oxidizing bacteria can be conveniently classified into two types depending on the pathway of carbon assimilation (Whittenbury et al., 1970). Type I organisms have a ribulose monophosphate (RMP) cycle whilst type II organisms have a serine cycle. In having an RMP cycle as its main carbon assimilation route (Strom et al., 1974), Methylococcus was originally considered to be a type I organism. However, the possible existence of an auxiliary serine pathway (Reed, 1976), the presence of ribulose-1,5-bisphosphate (RuBP) carboxylase in at least two Methylococcus strains (Taylor, 1979) and a DNA base composition of $62.5 \mathrm{~mol} \%$ GC has led Whittenbury \& Dalton (1980) to re-classify Methylococcus as a type $\mathrm{X}$ methylotroph.

The presence of RuBP carboxylase and phosphoribulokinase in M. capsulatus (Bath) has been demonstrated (Taylor, 1977). However, as reported here, this organism does not appear to grow autotrophically at the expense of $\mathrm{CO}_{2}$. This paper attempts to establish a possible role for RuBP carboxylase in relation to the overall carbon metabolism of this organism.

\section{METHODS}

Growth of organisms and preparation of cell-free extracts. Methylococcus capsulatus (Bath) (Whittenbury et al., 1970) was grown as a chemostat culture in a 31 fermenter (L.H. Engineering, Stoke Poges, Bucks.) on ammonium mineral salts (AMS) medium (Dalton \& Whittenbury, 1976). The chemostat was operated under oxygen limitation with methane $(20 \%, \mathrm{v} / \mathrm{v}$, in air at a flow rate of $50 \mathrm{ml} \mathrm{min}-1)$ as carbon source. Temperature and

† Present address: I.C.I. Corporate Laboratory, The Heath, Runcorn, Cheshire WA7 4PE. 
$\mathrm{pH}$ were maintained at $45^{\circ} \mathrm{C}$ and 6.8 , respectively. A dilution rate $(D)$ of $0.15 \mathrm{~h}^{-1}$ was used and at steady state the dry weight of the culture was $4 \mathrm{mg} \mathrm{ml}^{-1}$. Methylomonas methanica (SI) was grown under the same conditions at $30^{\circ} \mathrm{C}$.

Cells were harvested by centrifugation at $10000 \mathrm{~g}$, washed twice with, and resuspended in $20 \mathrm{~mm}-\mathrm{Tris} / \mathrm{HCl}$,

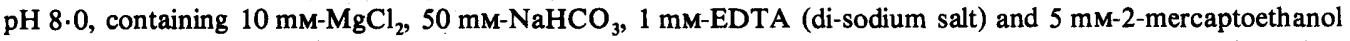
(Tabita \& McFadden, 1974). Crude cell extracts were prepared by two passages of the suspension through a pre-cooled French press (American Instrument Co., Maryland, U.S.A.) at $137 \mathrm{MPa}$. Unbroken cells and debris were removed by centrifugation $(10000 \mathrm{~g}$ for $10 \mathrm{~min}$ ) and the supernatant was further centrifuged $(120000 \mathrm{~g}$ for $1.5 \mathrm{~h}$ ) to yield soluble and particulate fractions.

For the attempted autotrophic growth of $M$. capsulatus (Bath), cultures were prepared in $250 \mathrm{ml}$ Erlenmeyer flasks, containing $20 \mathrm{ml}$ of either AMS or nitrate mineral salts (NMS) medium (Dalton \& Whittenbury, 1976) and sealed with rubber serum caps. $\mathrm{CO}_{2}$ was added as filter-sterilized $\mathrm{NaHCO}_{3}$ (final concentration 0.01 to $0.1 \%$, $\mathrm{w} / \mathrm{v})$. Hydrogen $(5$ to $50 \mathrm{ml}$ ) was added to the gas phase and other potential electron donors were added directly to the culture (final concentration 0.005 to $0.1 \%$, w/v). Inocula were taken from a chemostat culture and flasks were incubated with shaking at $45^{\circ} \mathrm{C}$.

Enzyme assays and units. RuBP carboxylase [3-phospho-D-glycerate carboxy-lyase (dimerizing); EC 4.1.1.39] was assayed by the RuBP-dependent incorporation of $\mathrm{NaH}^{14} \mathrm{CO}_{3}$ into acid stable products (Taylor, 1977). Fructose-1,6-bisphosphatase [D-fructose-1,6-bisphosphate 1-phosphohydrolase; EC 3.1.3.11] was assayed by measuring the liberation of inorganic phosphate from fructose 1,6-bisphosphate by the method of Pontremoli (1966). Inorganic phosphate was estimated with the amidol reagent of Allen (1940). Phosphoglycollate phosphatase [2-phosphoglycollate phosphohydrolase; EC 3.1.3.18] was assayed by the method of Anderson \& Tolbert (1966).

Assays were done at $45^{\circ} \mathrm{C}$ for $M$. capsulatus (Bath) and $30^{\circ} \mathrm{C}$ for Methylomonas methanica (SI). One enzyme unit is the amount of enzyme that catalyses the transformation of $1 \mu \mathrm{mol}$ substrate min $^{-1}$ under the assay conditions described.

Measurement of $\mathrm{CO}_{2}$ fixation by intact cells. Cells were harvested by centrifugation (10000 $\mathrm{g}$ for $10 \mathrm{~min}$ ) washed once with, and resuspended to an $A_{540}$ of 0.1 in AMS medium at $45^{\circ} \mathrm{C}$. Methane $(25 \mathrm{ml})$ was added to a $20 \mathrm{ml}$ suspension in a $250 \mathrm{ml}$ Erlenmeyer flask sealed with a rubber serum cap, and equilibrated at $45^{\circ} \mathrm{C}$ for 10

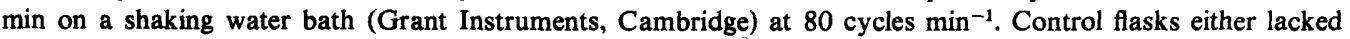
methane or contained heat-killed cells. $\mathrm{NaHCO}_{3}$ (final concentration $2.5 \mathrm{~mm}$ ) was then added, followed, after a further $10 \mathrm{~min}$, by $10 \mu \mathrm{Ci}(370 \mathrm{kBq}) \mathrm{NaH}^{14} \mathrm{CO}_{3}$ to give a final specific activity of $0.2 \mu \mathrm{Ci} \mu \mathrm{mol}^{-1}(7.4 \mathrm{kBq}$ $\left.\mu \mathrm{mol}^{-1}\right)$. At $10 \mathrm{~min}$ intervals a $1 \mathrm{ml}$ sample was transferred to a scintillation vial containing $2.0 \mathrm{ml} 95 \%(\mathrm{v} / \mathrm{v})$ ethanol $/ 5 \%(\mathrm{v} / \mathrm{v})$ glacial acetic acid. Samples were evaporated to dryness, resuspended in $1.0 \mathrm{ml}$ distilled water and radioactivity (fixed ${ }^{14} \mathrm{C}$ ) was measured.

Radiotracer studies. Cells were harvested by centrifugation $(10000 \mathrm{~g}$ for $10 \mathrm{~min})$, washed once with, and resuspended in $10 \mathrm{ml}$ AMS medium to a density of either $10 \mathrm{mg} \mathrm{ml}^{-1}$ (for $\mathrm{NaH}^{14} \mathrm{CO}_{3}$ incorporation) or $5 \mathrm{mg} \mathrm{ml}^{-1}$ (for [1-14 Clglycollate incorporation). The suspension, in a $50 \mathrm{ml}$ round-bottomed flask sealed with a rubber serum cap and partially submerged in a water bath at $45^{\circ} \mathrm{C}$, was aerated by stirring with a magnetic follower. After 5 min equilibration, $10 \mathrm{ml}$ methane was injected into the flask followed, after $10 \mathrm{~min}$, by the ${ }^{14} \mathrm{C}$ substrate $[200 \mu \mathrm{Ci}$ $(7.4 \mathrm{MBq}) \mathrm{NaH}^{14} \mathrm{CO}_{3}$ or $50 \mu \mathrm{Ci}(1.85 \mathrm{MBq})\left[1{ }^{14} \mathrm{C}\right]$ giycollate $]$. At various intervals a $1 \mathrm{ml}$ sample was removed by syringe and added to $4 \mathrm{ml}$ hot $\left(60^{\circ} \mathrm{C}\right)$ absolute ethanol. The resulting precipitate was removed by centrifugation and further extracted with two changes of $50 \%(\mathrm{v} / \mathrm{v})$ hot ethanol. The supernatants were combined and the volume was reduced to $0.5 \mathrm{ml}$ in a vacuum rotary evaporator (Quickfit).

Radioactive compounds were separated by two-dimensional ascending paper chromatography on Whatman no. 1 chromatography paper. The solvent system was phenol/water/glacial acetic acid/EDTA (1 M) (840:149:10:1, by vol.) in the first dimension and equal volumes of propionic acid/water $(620: 790, \mathrm{v} / \mathrm{v})$ and 1-butanol/water $(1246: 84, v / v)$ in the second dimension. The position of labelled metabolites was determined by exposing the dried chromatograms to 'Kodirex' X-ray film for 1 month. The radioactivity per metabolite was measured by cutting out radioactive areas of the chromatograms and counting these in a liquid scintillation spectrometer using a Triton/toluene scintillation fluid [6] toluene, 31 Triton X-100, $36 \mathrm{~g}$ 2,5-diphenyloxazole, $0.45 \mathrm{~g} 1,4$-di2-(5-phenyloxazolyl)benzene]. Radioactive areas from duplicate chromatograms were cut out, eluted with $50 \%$ $(\mathrm{v} / \mathrm{v})$ ethanol and re-chromatographed with a series of standards. Metabolites were positively identified when they co-chromatographed with the authentic standard. Amino acids were detected with $0.25 \%(\mathrm{w} / \mathrm{v})$ ninhydrin in acetone, carboxylic acids with $0.1 \%(\mathrm{w} / \mathrm{v})$ bromocresol green $(\mathrm{pH} \mathrm{5.0)}$ in ethanol and phosphorylated compounds by the method of Bandurski \& Axelrod (1951).

Chemicals. All chemicals were the best grade available and were obtained from Sigma or BDH. Radiochemicals were purchased from The Radiochemical Centre, Amersham. Before use sodium $\left[1-{ }^{14} \mathrm{C}\right]$ glycollate was purified by paper chromatography on Whatman no. 1 paper (Long et al., 1951). 


\section{RESULTS AND DISCUSSION}

\section{$\mathrm{CO}_{2}$ fixation by methane-grown M. capsulatus (Bath)}

Intact cells, incubated in the presence of methane, showed a linear rate of $\mathrm{CO}_{2}$ fixation over a 10 to $60 \mathrm{~min}$ period of $0.23 \mu \mathrm{mol} \mathrm{CO}_{2}$ fixed h $\mathrm{h}^{-1}(\mathrm{mg} \text { dry wt })^{-1}$. No significant fixation was observed in the absence of methane indicating the probable energy dependence of $\mathrm{CO}_{2}$ fixation in this organism. This measured rate is probably an underestimate of the true fixation rate because of (i) dilution of radioactive $\mathrm{CO}_{2}$ during assay by endogenously produced $\mathrm{CO}_{2}$ and (ii) the effect of washing and resuspension of cells in fresh growth medium. However, assuming a protein content of 60 to $70 \%$ of the dry weight, the measured rate of $\mathrm{CO}_{2}$ fixation agrees with the specific activity of RuBP carboxylase in cell-free extracts $[6 \mathrm{~m}$-unit (mg protein) ${ }^{-1}$ ]. Taking the formula for cell material to be $\mathrm{C}_{4} \mathrm{H}_{8} \mathrm{NO}_{2}$ (Maclennan et al., 1971; Goldberg et al., 1976) then the measured rate of $\mathrm{CO}_{2}$ fixation suggests that approximately $2.5 \%(\mathrm{w} / \mathrm{w})$ of cell carbon originates from $\mathrm{CO}_{2}$.

This measure of $\mathrm{CO}_{2}$ fixation does not differentiate between that catalysed by known heterotrophic reactions and that catalysed by RuBP carboxylase. To investigate further the fate of $\mathrm{CO}_{2}$, the early time course of labelling of pool metabolites following fixation of ${ }^{14} \mathrm{CO}_{2}$ was examined. The amounts of radioactivity in various metabolites, expressed as percentages of the total radioactivity in the sample at various time intervals, are shown in Table 1 .

The decrease with time of the percentage of incorporated label in 3-phosphoglycerate and total phosphate esters indicates that RuBP carboxylase does function in vivo. Similar decreases in the percentage of incorporated label in malate, citrate and aspartate indicate that $\mathrm{CO}_{2}$ is also fixed by carboxylation of $\mathrm{C}_{3}$ metabolites yielding $\mathrm{C}_{4}$ dicarboxylic acids and hence, by transamination, aspartate. The pattern of labelling (Table 1) is similar to that reported for many autotrophic bacteria when grown heterotrophically (Fuller et al., 1961; Anderson \& Fuller, 1967; Slater \& Morris, 1973). Furthermore, the specific activity of RuBP carboxylase in cell-free extracts $\left.[6 \mathrm{~m} \text {-unit (mg protein })^{-1}\right]$ was similar to that found in cell-free extracts of heterotrophically grown autotrophs.

\section{The potential for autotrophic growth in M. capsulatus (Bath)}

Apart from RuBP carboxylase and phosphoribulokinase, the only other essential enzyme of the Calvin cycle which is not present in M. capsulatus (Bath) as part of the RMP cycle is

Table 1. Percentage incorporation of ${ }^{14} \mathrm{CO}_{2}$ into pool metabolites of M. capsulatus (Bath) at $45^{\circ} \mathrm{C}$

\begin{tabular}{|c|c|c|c|c|c|c|}
\hline \multirow[b]{3}{*}{ Metabolite } & \multicolumn{6}{|c|}{ Radioactivity in metabolite ( $\%$ of total in sample) } \\
\hline & \multicolumn{6}{|c|}{ Sample time: } \\
\hline & $10 \mathrm{~s}$ & $20 \mathrm{~s}$ & $40 \mathrm{~s}$ & $60 \mathrm{~s}$ & $2 \mathrm{~min}$ & $4 \mathrm{~min}$ \\
\hline 3-Phosphoglycerate & $27 \cdot 3$ & $13 \cdot 0$ & $20 \cdot 1$ & $13 \cdot 7$ & $15 \cdot 6$ & $4 \cdot 5$ \\
\hline Aspartate & 37.7 & $26 \cdot 0$ & $23 \cdot 5$ & $15 \cdot 8$ & $9 \cdot 3$ & $3 \cdot 5$ \\
\hline Citrate & 14.6 & $8 \cdot 5$ & 7.4 & $7 \cdot 1$ & $5 \cdot 3$ & $3 \cdot 3$ \\
\hline Malate & 20.4 & $18 \cdot 2$ & $15 \cdot 8$ & $20 \cdot 5$ & $15 \cdot 6$ & $8 \cdot 2$ \\
\hline Phosphoenolpyruvate & - & 5.9 & 4.9 & $3 \cdot 8$ & 2.8 & $1 \cdot 5$ \\
\hline Other phosphate esters & - & $6 \cdot 5$ & $4 \cdot 5$ & 9.7 & $6 \cdot 5$ & $6 \cdot 3$ \\
\hline Glutamate & - & 8.4 & 11.4 & $17 \cdot 4$ & $26 \cdot 7$ & $27 \cdot 5$ \\
\hline Alanine & - & 7.6 & 7.4 & 6.9 & $6 \cdot 9$ & $5 \cdot 6$ \\
\hline Succinate & - & 5.9 & $5 \cdot 0$ & $5 \cdot 1$ & $5 \cdot 2$ & $2 \cdot 5$ \\
\hline Glutamine & - & - & - & - & $2 \cdot 0$ & 2.7 \\
\hline Leu/Ile/Phe & - & - & - & - & $4 \cdot 1$ & 28.6 \\
\hline Threonine & - & - & - & - & - & $1 \cdot 5$ \\
\hline Serine + Glycine & - & - & - & - & - & 1.9 \\
\hline Unidentified compounds & - & - & - & - & - & 2.4 \\
\hline
\end{tabular}


Table 2. Percentage incorporation of $\left[1-{ }^{14} \mathrm{C}\right] \mathrm{glycollate}$ into pool metabolites of M. capsulatus (Bath)

\begin{tabular}{rcccc}
\multicolumn{5}{c}{ Radioactivity in metabolite (\% of total in sample) } \\
\hline $\begin{array}{r}\text { Sample time: } \\
\text { min }\end{array}$ & $4 \mathrm{~min}$ & $8 \mathrm{~min}$ & $12 \mathrm{~min}$ & $16 \mathrm{~min}$ \\
6.0 & 10.3 & 10.1 & 12.5 & 15.3 \\
27.4 & 23.9 & 17.0 & 15.1 & 18.5 \\
15.3 & 27.5 & 22.0 & 21.0 & 17.7 \\
13.5 & 3.6 & - & - & - \\
8.9 & - & - & - & - \\
6.8 & - & - & - & - \\
5.9 & - & - & - & - \\
- & 4.8 & 2.9 & 1.4 & - \\
$\overline{6.5}$ & 4.0 & 2.3 & 1.9 & 1.7 \\
9.7 & 20.9 & 28.0 & 30.6 & 32.3 \\
& 5.0 & 17.7 & 17.5 & 14.5
\end{tabular}

fructose-1,6-bisphosphatase. This enzyme was detected in the soluble fraction of cell-free extracts at a specific activity of 5 m-unit (mg protein) $)^{-1}$.

Formate, ethanol and hydrogen are all oxidized by $M$. capsulatus (Bath) and may be considered potential electron donors for autotrophic growth (Dalton \& Whittenbury, 1976). However, none of these compounds in combination with $\mathrm{CO}_{2}$ supported detectable growth on incubation for 3 weeks. Therefore, although the enzymes of the Calvin cycle are present in this organism, evidence so far suggests that $\mathrm{CO}_{2}$ cannot be utilized as the sole source of carbon for growth.

\section{Metabolism of glycollate by M. capsulatus (Bath)}

The previously unexplained formation of glycollate from $\left[{ }^{14} \mathrm{C}\right]$ methanol (Reed, 1976) may result from the oxygenase activity of RuBP carboxylase (Taylor et al., 1980) in generating phosphoglycollate from RuBP.

The soluble fraction of cell-free extracts of $M$. capsulatus (Bath) does contain a specific phosphoglycollate phosphatase with a specific activity of 37 m-unit (mg protein) $)^{-1}$. This enzyme was not detected in Methylomonas methanica (SI), a type I methylotroph with an RMP cycle but with no RuBP carboxylase.

The further metabolism of glycollate by $M$. capsulatus (Bath) was investigated by examining the incorporation of $\left[1{ }^{14} \mathrm{C}\right]$ glycollate by intact cells. A linear rate of incorporation was observed over $20 \mathrm{~min}$ corresponding to 3000 c.p.m. incorporated $\min ^{-1}\left(\mathrm{mg} \mathrm{dry} \mathrm{wt}^{-1}\right.$. The time course of labelling is shown in Table 2. The majority of label appearing initially in serine plus glycine probably represents the formation of glycine from glycollate via glyoxylate, the presence of which would not be shown by the chromatography system used. The absence of large amounts of label initially in phosphate esters argues against the tartronic semialdehyde pathway (Kornberg \& Gotto, 1961; Codd \& Stewart, 1973) being an important route for glycollate metabolism in this organism. The increase in the percentage of incorporated label in phosphate esters probably indicates the conversion of glycine and serine to these compounds. The lack of label in the tricarboxylic acid cycle intermediates suggests that glycollate is not significantly metabolized via either a glyoxylate cycle or $\beta$-hydroxyaspartate pathway (Kornberg \& Morris, 1965). This then leads to the possibility that glycollate may be incorporated into cell carbon by a pathway similar to that found in higher plants (Fig. 1) and analogous to part of the serine cycle for $C_{1}$ assimilation (Large \& Quayle, 1963) in type II methylotrophs.

Although the mechanism of a glycine to serine conversion has not been elucidated, the 
2-Phosphoglycollate

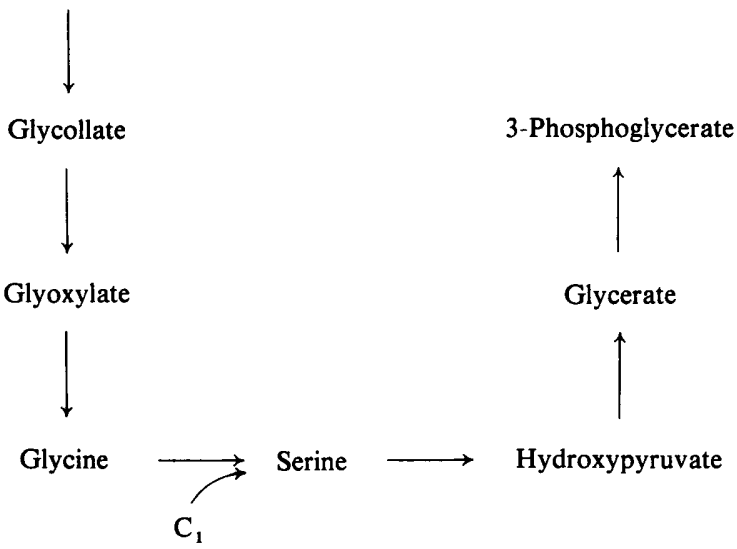

Fig. 1. Postulated pathway of incorporation of glycollate into cell carbon.

labelling of serine after incorporation of $\left[{ }^{14} \mathrm{C}\right]$ formate, recorded by both Eccleston \& Kelly (1973) and Whittenbury et al. (1976), suggests that formate, probably as a tetrahydrofolate derivative, may combine with glycine to give serine.

The presence of hydroxypyruvate reductase in M. capsulatus (Bath) (Whittenbury et al., 1976; J. R. Quayle, personal communication), with activities of 40 to 60 m-unit (mg protein $)^{-1}$, has previously been unexplained. This enzyme may be involved in the conversion of serine to phosphate esters, and its requirement in phosphoglycollate metabolism in $M$. capsulatus (Bath) may also be the reason for its apparent 'transvestite' appearance in Paracoccus denitrificans growing autotrophically on methanol (Bamforth \& Quayle, 1977).

This work was supported by a grant from the British Petroleum Co. Ltd (to S. C. Taylor). We thank Mr P. P. Taylor for his excellent technical assistance.

\section{REFERENCES}

AllEN, R. J. L. (1940). The estimation of phosphorus. Biochemical Journal 34, 858-865.

ANDERSON, L. \& Fuller, R. C. (1967). Photosynthesis in Rhodospirillum rubrum. 1. Autotrophic carbon dioxide fixation. Plant Physiology 42, 487490.

Anderson, L. \& Tolbert, N. E. (1966). Phosphoglycollate phosphatase. Methods in Enzymology 9, 646-650.

BAMFORTH, C. W. \& QuAYLE, J. R. (1977). Hydroxypyruvate reductase activity in Paracoccus denitrificans. Journal of General Microbiology 101, 259267.

Bandurski, R. S. \& Axelrod, B. (1951). Chromatographic identification of some biologically important esters. Journal of Biological Chemistry 193, 405410.

Codd, G. A. \& Stewart, W. D. P. (1973). Pathways of glycollate metabolism in the blue-green alga Anabaena cylindrica. Archiv für Mikrobiologie 94, 11-28.

Dalton, H. \& Whittenbury, R. (1976). The acetylene reduction technique as an assay for the nitrogenase activity in the methane oxidising bacterium Methylococcus capsulatus strain Bath. Archives of Microbiology 109, 147-151.

Eccleston, M. \& Kelly, D. P. (1973). Assimilation and toxicity of some exogenous $C_{1}$ compounds, alcohols, sugars and acetate in the methaneoxidizing bacterium Methylococcus capsulatus. Journal of General Microbiology 75, 211-221.

Fuller, R. C., Smillie, R. M., Sisler, E. C. \& KornberG, H. L. (1961). Carbon metabolism in Chromatium. Journal of Biological Chemistry 236, 2140-2149.

GoldberG, I., Rock, J. S., Ben-BAsSat, A. \& MATELES, R. I. (1976). Bacterial yields on methanol, methylamine, formaldehyde and formate. Biotechnology and Bioengineering 18, 1657-1668.

KornberG, H. L. \& GotTo, A. M. (1961). The metabolism of $\mathrm{C}_{2}$ compounds in micro-organisms. 6. Synthesis of cell constituents from glycollate by Pseudomonas sp. Biochemical Journal 78, 69-82.

Kornberg, H. L. \& Morris, J. G. (1965). The utilisation of glycollate by Micrococcus denitrificans: the $\beta$-hydroxyaspartate pathway. Biochemical Journal 95, 577-586. 
LARGE, P. J. \& QuAYle, J. R. (1963). Microbial growth on $C_{1}$ compounds. V. Enzyme activities in extracts of Pseudomonas AM1. Biochemical Journal 87, 386-396.

Long, A. G., Quayle, J. R. \& Stedman, R. J. (1951). The separation of acids by paper partition chromatography. Journal of the Chemical Society, Part III, 2197-2201.

Maclennan, D. G., Ousby, J. C., Vasey, R. B. \& Cotron, N. T. (1971). The influence of dissolved oxygen on Pseudomonas AM1 grown on methanol in continuous culture. Journal of General Microbiology 69, 395-404.

Pontremol, S. (1966). Fructose 1,6-diphosphatase. 1. Rabbit liver (crystalline). Methods in Enzymology 9, 625-631.

REED, H. L. (1976). A study of certain unusual biochemical and physiological properties of obligate methane-utilising bacteria. Ph.D. thesis, University of Warwick.

Slater, J. H. \& Morris, I. (1973). Photosynthetic carbon dioxide assimilation by Rhodospirillum rubrum. Archiv für Mikrobiologie 88, 213-223.

Strom, T., Ferenci, T. \& Quayle, J. R. (1974). The carbon assimilation pathways of Methylococcus capsulatus, Pseudomonas methanica and Methylosinus trichosporium (OB3B) during growth on methane. Biochemical Journal 144, 465-476.

TABITA, F. R. \& MCFADDEN, B. A. (1974). D-Ribulose 1,5-diphosphate carboxylase from Rhodospirillum rubrum. 1. Levels, purification and effects of metallic ions. Journal of Biological Chemistry 244, 34533458.

TAYLOR, S. C. (1977). Evidence for the presence of ribulose 1,5-bisphosphate carboxylase and phosphoribulokinase in Methylococcus capsulatus (Bath). FEMS Microbiology Letters 2, 305-307.

TAYLOR, S. C. (1979). Ribulose 1,5-bisphosphate carboxylase and carbon dioxide fixation in Rhodo. microbium vannielii (RM5) and Methylococcus capsulatus (Bath). Ph.D. thesis, University of Warwick.

Taylor, S. C., Dalton, H. \& Dow, C. S. (1980). Purification and initial characterization of ribulose 1,5-bisphosphate carboxylase from Methylococcus capsulatus (Bath). FEMS Microbiology Letters 8, $157-160$.

WhittenbuRy, R. \& Dalton, H. (1980). The methylotrophic bacteria. In The Prokaryotes. Edited by M. P. Starr, H. Stolp, H. G. Trüper, A. Balows \& H. G. Schlegel. Berlin: Springer-Verlag (in the Press).

Whittenbury, R., Phillips, K. C. \& Wilkinson, J. F. (1970). Enrichment, isolation and some properties of methane-utilizing bacteria. Journal of General Microbiology 61, 205-218.

Whittenbury, R., Colby, J., Dalton, H. \& Reed, H. L. (1976). Biology and ecology of methane oxidisers. In Symposium on Microbial Production and Utilisation of Gases $\left(\mathrm{H}_{2}, \mathrm{CH}_{4}, \mathrm{CO}\right)$, pp. 281293. Edited by H. G. Schlegel, G. Gottschalk \& N. Pfennig. Göttingen: Akademie der Wissenschaften, Göttingen. 